\title{
MORFOLOGI KOTA-KOTA DI PRIANGAN TIMUR PADA ABAD XX - XXI; STUDI KASUS KOTA GARUT, CIAMIS, DAN TASIKMALAYA
}

\section{CITIES MORFOLOGI IN EAST PRIANGAN OF THE $20^{T H}$ AND $21^{\text {ST }}$ CENTURY: A CASE STUDY OF GARUT, CIAMIS AND TASIKMALAYA}

\author{
Miftahul Falah, Nina Herlina, Kunto Sofianto \\ Program Studi Sejarah, Fakultas Ilmu Budaya, Universitas Padjadjaran \\ miftahul.falah@unpad.ac.id,nina.herlina@unpad.ac.id, kunto.sofianto@unpad.ac.id \\ Naskah Diterima:4 Januari 2017 Naskah Direvisi:10 Februari $2017 \quad$ Naskah Disetujui: 17 Februari 2017
}

\begin{abstract}
Abstrak
Tulisan ini akan mengkaji perubahan Morfologi Kota-Kota di Priangan Timur pada Abad XX-XXI dengan memfokuskan pada Kota Garut, Ciamis, dan Tasikmalaya. Untuk mencapai tujuan itu, dalam penelitian ini digunakan metode sejarah yang meliputi empat tahap yakni heuristik, kritik, interpretasi, dan historiografi. Hasil penelitian menunjukkan bahwa pertumbuhan morfologi kota dengan mengkaji tata ruang dan infrastruktur kota, simbol kota, bangunan, dan ruang terbuka di Kota Garut, Ciamis, dan Tasikmalaya menunjukkan kecenderungan yang berbeda. Pada awalnya, struktur dan pola kota ketiganya menunjukkan kecenderungan yang sama karena mendapat pengaruh struktur kota tradisional. Akan tetapi, dalam perkembangannya menunjukkan perbedaan yang terlihat dari struktur dan pola kota Tasikmalaya yang cenderung mengabaikan struktur dan pola kota tradisional. Unsur-unsur kota kolonial di ketiga kota tersebut cukup nampak sehingga terjadi perpaduan antara kota tradisional dan kota kolonial yang salah satunya terlihat dari bangunan yang mendapat pengaruh budaya indis.
\end{abstract}

Kata kunci: Morfologi Kota, Garut, Ciamis, Tasikmalaya

\section{Abstract}

This paper examines the morphology changes of Cities in East Priangan in the $20^{\text {th }}$ and $21^{\text {st }}$ century by focusing on the city of Garut, Ciamis and Tasikmalaya. To achieve that goal, this study uses historical method which includes four stages of heuristics, criticism, interpretation, and historiography. The results showed that the growth of the city by studying morphology and spatial infrastructure of the city, a symbol of the city, buildings and open spaces in the city of Garut, Ciamis and Tasikmalaya shows a different trend. At first, the structure and pattern of the three cities showed the same tendency as under the influence of traditional city structures. However, in its development shows the differences seen from the structure and pattern of Tasikmalaya which tends to undermine the structure and pattern of traditional town. The elements of the colonial city in the three cities are quite visible, causing a blend of traditional and colonial city. One of which is visible from the building that received cultural influences of Indies.

Keywords: Morphology City, Garut, Ciamis, Tasikmalaya

\section{A. PENDAHULUAN}

Kawasan perkotaan merupakan sebuah kawasan yang memiliki kegiatan utama masyarakatnya bukan di sektor pertanian. Oleh karena itu, sebuah wilayah dikatakan sebagai kawasan perkota-an apabila wilayah tersebut memiliki fungsi sebagai kawasan pemukiman per-kotaan, pemusatan dan distribusi pela-yanan jasa pemerintahan, pelayanan sosial, dan kegiatan ekonomi (Pontoh \& Kustiawan, 2009: 8). Dengan demikian, harus dibedakan antara kawasan per-kotaan dengan kota karena istilah ter-akhir merujuk pada wilayah yang jauh lebih luas daripada istilah pertama. Di sisi lain, dalam struktur pemerintahan daerah, terdapat istilah kota yang merujuk pada wilayah 
adiministrasi pemerintahan tingkat dua yang dipimpin oleh seorang walikota. Istilah ini tentu saja memiliki pengertian dan makna yang berbeda dengan istilah sebagai-mana dikemukakan oleh Pontoh dan Kustiawan di atas. Meskipun demikian, dalam tulisan ini, istilah kota ditujukan pula untuk kawasan perkotaan yang menjadi pusat pemerintahan pemerintah-an kota dan kabupaten.

Di Priangan Timur, terdapat beberapa kota dan kawasan perkotaan utama yang berbanding lurus dengan jumlah wilayah pemerintahan kota dan kabupaten. Di wilayah ini, terdapat lima kota dan kawasan perkotaan yang menjadi pusat pemerintahan kota atau kabupaten yaitu Kota Garut, Ciamis, Kota Tasik-malaya, Kota Banjar, dan Kota Parigi. Kota-kota tersebut telah tumbuh sede-mikian rupa sehingga memperlihatkan pola kota seperti saat ini. Tiga kota pertama, akan menjadi objek kajian tulisan ini. ${ }^{1}$ Pertumbuhan tersebut sudah tentu mendapat pengaruh dari berbagai faktor, antara lain sejarahnya, demo-grafi, politik, ekonomi, sosial, dan buda-ya. Menarik untuk diteliti bagaimana perubahan morfologi ketiga kota ter-sebut pada Abad XX melalui kajian bentuk struktur, pola, dan simbol kota?

Dengan menggunakan pendekatan morfologi kota, artikel ini dapat menjelaskan secara historis perubahan morfologi Kota Garut, Ciamis, dan Tasikmalaya pada Abad XX. Kajiannya difokuskan pada bentuk struktur dan pola kota (tata ruang kota), serta simbol kota sebagai salah satu unsur pembentuk identitas kota. Pemilihan ketiga kota tersebut berdasarkan pada fakta historis bahwa ketiganya memiliki sejarah yang sangat panjang sebagai pusat aktivitas politik, ekonomi, sosial, dan budaya di masing-masing wilayah. Oleh karena itu, kajian atas morfologi kota Garut, Ciamis,

\footnotetext{
${ }^{1}$ Kajian morfologi ketiga kota tersebut merupakan bagian dari penelitian disertasi yang mengkaji Pertumbuhan Morfologi Kota-Kota Pusat Pemerintahan di Priangan pada Abad XX-XXI.
}

dan Tasikmalaya sangat penting dilakukan untuk melengkapi kajian his-toris yang sudah ada sebelumnya. Selain itu, untuk dijadikan sebagai bahan pertimbangan terhadap rencana tata ruang kota yang berbasiskan historis.

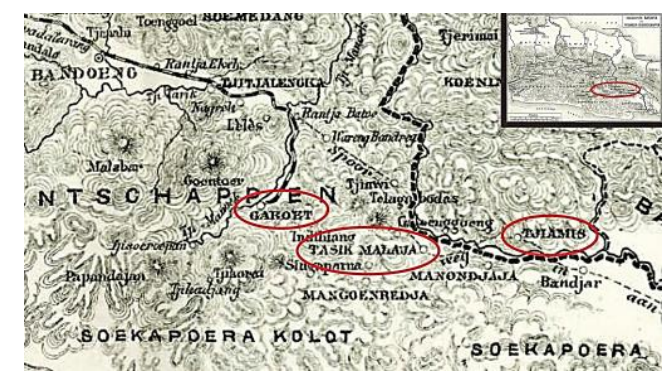

Gambar 1. Lokasi Kota Garut, Tasikmalaya, dan Ciamis

Sumber: M. Buys. 1891. Batavia, Buitenzorg, en de Preanger; Gids voor Bezoekers en Toeristen. Batavia: G. Kolff \& Co.

\section{METODE PENELITIAN}

Metode penelitian yang dipergunakan dalam penelitian ini adalah metode sejarah yakni "The process of citically examining and analyzing the records and survivals of the past. The imaginative reconstruction of the past from the data derived by the process is called historiography" (Gottschalk, 1968: 48). Dalam tataran operasional, metode sejarah dilakukan dalam empat tahap. Pertama heuristik yakni proses mencari, menemukan, dan menghimpun sumber sejarah yang relevan dengan pokok masalah yang sedang diteliti. Heuristik dilakukan di berbagai perpus-takaan, antara lain di Perpustakaan Na-sional Republik Indonesia (Jakarta), Perpustakaan Pusat TNI Angkatan Darat (Bandung), Perpustakaan Daerah Pro-vinsi Jawa Barat (Bandung), Perpustaka-an Pusat Universitas Padjadjaran (Ban-dung), Universiteitsbibliotheek Leiden, Koninklijk Bibliotheek (Den Haag), dan Bibliotheek Museum Volkenkunde (Lei-den). Selain itu, heuristik pun dilakukan dengan menelusuri sumber di Arsip Na-sional Republik Indonesia (Jakarta), Nationaal Archief (Den Haag), dan Tropenmuseum Royal Instituut (Ams-terdam). 
Dari heuristik yang telah dilaku-kan, selain memperoleh sumber primer, juga diperoleh beberapa sumber se-kunder berupa buku, disertasi, dan ar-tikel ilmiah. Beberapa buku menun-jukkan keterkaitan topik dengan artikel ini antara lain Garut Kota Intan (Kunto Sofianto, 2001), Sejarah Kota Tasik-malaya, 1820-1942 (Miftahul Falah, 2010), Sejarah Kota-Kota Lama di Jawa Barat (Nina Herlina Lubis et al., 2013), dan Sejarah Kabupaten Ciamis (Nina Herlina Lubis et al., 2013). Buku-buku tersebut menguraikan secara kompre-hensif pertumbuhan kota/kabupaten se-cara menyeluruh yang meliputi aspek politik, ekonomi, sosial, dan budaya. Pertumbuhan morfologi kota tidak menjadi kajian utama dalam bukubuku tersebut, sementara artikel ini bertujuan melakukan kajian pertumbuhan kota secara morfologis.

Ada dua disertasi yang berkaitan dengan objek kajian dalam artikel ini. Ronald Gilbert Gill pada 1995, menulis disertasi yang berjudul De Indische Stad op Java en Madoera; Een Morfolo-gische Studie van haar Ontwikkeling yang membahas perkembangan dan struktur bangunan bergaya Belanda, perencanaan kota, dan penempatan alun-alun dalam konstelasi tata ruang kota-kota di Jawa dan Madura. Dalam ruang terbatas, disertasi hanya menyinggung sepintas tata ruang Kota Garut dan Ciamis, karena objek kajian disertasi ini kota-kota di Jawa Tengah dan Jawa Timur.

Lely Yulifar, di bawah arahan A. Sobana Hardjasaputra sebagai pro-motor, melakukan penelitian untuk penulisan disertasi berjudul Kabupaten GaluhCiamis, 1809-1942. Dalam diser-tasi yang berhasil dipertahankan pada 2014 itu, Lely memfokuskan kajiannya pada dinamika Kabupaten Galuh yang pada 1 Januari 1926 berubah nama menjadi Kabupaten Ciamis. Aspek morfologi kota Ciamis tidak dikaji secara khusus sehingga menunjukkan perbedaan dengan penelitian ini.
Beberapa tulisan yang terdapat dalam jurnal ilmiah, menyinggung ketiga kota yang dikaji dalam artikel ini. Pada 2009, Miftahul Falah menulis sebuah artikel berjudul "Pertumbuhan Kota Tasikmalaya (1820-1942); Dari Kota Distrik menjadi Kota Kabupaten" yang diterbitkan oleh jurnal Metahuma-niora. Pada 2012, penulis yang sama, menulis artikel berjudul "Pers di Kota Tasikmalaya, 1900-1942" yang diterbit-kan oleh jurnal Sosiohumaniora. Kedua artikel tersebut memiliki kesamaan objek kajian dengan artikel ini, tetapi uraiannya tidak membahas perubahan morfologi Kota Tasikmalaya. Sementara artikel ini bertujuan mengkaji pertum-buhan morfologi Kota Tasikmalaya.

Dalam spasial yang luas, Mumuh Muhsin Zakaria menulis artikel berjudul "Priangan Abad Ke-19, Tinjauan Seja-rah dan Demografi" yang diterbitkan oleh jurnal Metahumaniora pada 2010. Penulis yang sama, menulis sebuah arti-kel Dinamika Sosial Ekonomi Priangan Abad Ke-19 yang diterbitkan oleh jurnal Sosiohumaniora pada 2011. Kedua artikel tersebut, menyinggung Kota Garut, Ciamis, dan Tasikmalaya, tetapi secara spesifikasi tidak menjelaskan pertumbuhan morfologi ketiga kota tersebut.

Dengan demikian, keempat artikel ilmiah tersebut menunjukkan perbedaan dengan artikel ini. Dari sumber-sumber sekunder/kontemporer tersebut, pertumbuhan morfologi Kota Garut, Ciamis, dan Tasikmalaya belum ada yang mengkaji. Umumnya, kajian yang dilakukan ber-sifat general history atau thematic history.

Selain menghimpun sumber mela-lui library research, proses heuristik dilakukan juga dengan melakukan field reseach dilakukan untuk menghimpun jejak historis di kota-kota yang menjadi kajian dalam penelitian ini. Pada saat sumber sejarah telah terhimpun, proses metode sejarah berlanjut dengan melakukan kritik sumber baik kritik ekstern (untuk menentukan otentisitas sumber) 
maupun kritik intern (untuk menentukan kredibilitas sumber). Hasil kritik ter-sebut adalah fakta sejarah yang kemu-dian diinterpretasi yakni proses me-nafsirkan baik secara verbalistis, teknis, faktual, logis, maupun psikologis. Hasil penafsiran tersebut kemudian dituang-kan dalam sebuah kisah sejarah yang ditulis secara kronologis. Dalam penu-lisan kisah sejarah tersebut, diperlukan imajinasi untuk menghidupkan kisah masa lampau tersebut dalam bentuk historiografi.

Untuk menghasilkan historiografi yang bersifat deskriptif-analitis, pendekatan yang dipergunakan dalam artikel ini adalah morfologi kota. Secara teoretis, fisik kota dapat terbentuk secara alamiah dan dibuat melalui perencanaan. Kota jenis pertama, tumbuh tanpa peren-canaan, tetapi dalam rentang waktu yang panjang tumbuh menjadi besar karena wilayahnya yang subur dan memiliki penduduk yang ulet dalam hubungannya dengan alam. Kota jenis kedua dibuat dengan perencanaan atas perintah penguasa (pribumi atau kolonial) untuk kepentingan tertentu (Antariksa, 2008). Beberapa kota di Priangan masuk ke dalam tipe kota yang dibangun atas perintah penguasa (kolonial) meskipun dalam tata ruang kota masih memper-lihatkan ekspresi sistem keagamaan, sosial, dan budaya serta hubungan dengan lingkungan dalam bentuk penataan komponen-komponen kota di dalam ruang-ruang tertentu. Untuk memahami morfologi kota-kota di Priangan jelas dibutuhkan pemahaman yang utuh mengenai perubahan tata kota secara diakronis. Perubahan tata kota yang terjadi di kota-kota pusat pemerintahan di Priangan tidak dapat dilepaskan dari adanya perubahan sosial budaya masyarakatnya, termasuk di dalamnya perubahan pandangan terha-dap alam lingkungannya. Hal tersebut sejalan dengan pendapat yang menga-takan bahwa pada masa lalu, tata kota terwujud tidak secara instan, melainkan berjalan setahap demi setahap, sehingga dapat dikenali urutan-urutan dalam pembentukan kota tersebut (Antariksa, 2008). Perubahanperubahan tata ruang kota tersebut dipengaruhi tiga faktor, yaitu dasar ekologi yang meng-untungkan, teknologi maju (relatif pada bentuk-bentuk pra-perkotaan) dalam kedua suasana, baik agrikultur maupun non-agrikultur, dan organisasi sosial yang kompleks dan di atas segalanya ada struktur kekuasaan yang betul-betul berkembang (Sjoberg, 1965).

\section{HASIL DAN BAHASAN 1. Priangan Timur dalam Arus Sejarah}

Secara geografi, Priangan Timur merupakan wilayah geografis paling timur dari sebuah wilayah yang bernama Priangan. ${ }^{2}$ Munculnya Priangan seiring dengan keruntuhan Kerajaan Sunda pada 1579 (Djajadiningrat, 1913/1983:102-103) yang salah satu dampaknya adalah memunculkan pusat politik baru di Tatar Sunda, di antaranya Sumedanglarang di bawah pimpinan Prabu Geuan Ulun (Ekadjati (ed.), 1984:102; Lubis, 1998). Setelah tahta Kerajaan Sumedanglarang diserahkan kepada Pangeran Suriadiwingsa I, pada 1620 eksistensi Kerajaan Sumedanglarang lenyap dan hanya berstatus sebagai kebupaten di bawah pengaruh politik Kesultanan Mataram (Ekadjati, 1982: 257). Seiring dengan itu,

\footnotetext{
${ }^{2}$ Priangan sebagai nama wilayah geografis di Jawa Barat sudah dikenal sejak abad XVII. Nama Priangan digunakan hingga sekarang meskipun luas dan batas-batas wilayah ini berubah-ubah. Luas wilayah Keresidenan Priangan pada abad XIX kurang lebih seperenam Pulau Jawa $\left(21.524 \mathrm{~km}^{2}\right)$. Batasbatas wilayah Keresidenan Priangan adalah Keresidenan Batavia dan Cirebon di sebelah Utara, Keresidenan Cirebon dan Banyumas di sebelah Timur, Samudera Hindia di sebelah selatan dan barat daya, dan Keresidenan Banten di sebelah Barat. Sementara itu, batas-batas alam wilayah ini adalah Gunung Salak \& Gunung Gede, Sungai Citanduy di sebelah Timur, Samudera Indonesia di sebalah Selatan, dan Pelabuhanratu dan Ciletu di sebelah Barat (Muhsin, 2011: 9; Stibbe, 1919: 503).
} 
nama Sumedanglarang berubah nama menjadi Priangan. ${ }^{3}$ Wilayah Priangan, ${ }^{4}$ menjadi ajang perebutan di antara tiga kekuatan, yaitu Banten, Mataram, dan VOC. Dari ketiga kekuatan politik tersebut, VOC tampil sebagai penguasa di Priangan setelah menerima wilayah Priangan dari Mataram pada 19-20 Oktober 1677 dan pada 5 Oktober 1705 (van Rees, 1880: 50-55). Setelah VOC dibubarkan pada 1799, kekuasaan atas wilayah Priangan diambil alih oleh Pemerintah Hindia Belanda dan Priangan

\footnotetext{
3 Hageman (1869: 180-181) telah mengumpulkan arti kata ataupun asal-usul nama Priangan dari berbagai sumber, salah satunya adalah sebagai berikut: kata priangan berasal dari kata prayangan yang artinya "memberikan atau menyerahkan dengan hati yang suci". Rupanya istilah ini dikaitkan dengan penyerahan diri Aria Suriadiwangsa kepada Sultan Mataram ini. Dalam sumbersumber Belanda istilah ini mulai disebut sekitar perempatan terakhir abad ke-17. Menurut Otto van Rees (1880: 2), istilah ini disebut-sebut oleh Komandan Jacob Couper tahun 1684 ketika ia atas perintah Gubernur Jenderal VOC memberikan acte van aanstellingen kepada para bupati Priangan. Semen-tara itu, Ajatrohaedi (1969, No. 187: 23 \& No. 195: 13) mengatakan bahwa istilah priangan merupakan sebuah kontraksi dari kata parahyangan yang artinya "tempat tinggal hyang (leluhur) yang harus dihormati".

4 Wilayah Priangan sangat subur karena merupakan daerah vulkanis yang dibentuk oleh gunung-gunung berapi dengan ketinggian antara 1.800 hingga $3.000 \mathrm{~m}$ di atas permukaan laut. Gunung-gunung tersebut di antaranya ada-lah Gunung Gede, Gunung Galunggung, Gu-nung Papandayan, Gunung Salak, Gunung Burangrang, Gunung Tangkuban Perahu, Gunung Guntur, dan Gunung Cikuray. Kondisi alam itulah yang mengakibatkan wilayah Priangan memiliki pegunungan dan gunung api yang cukup banyak, suatu keadaan yang sangat jarang ditemukan di belahan dunia lainnya (Stibbe, 1919: 503)
}

dijadikan sebagai salah satu wilayah pemerintahan setingkat keresidenan. ${ }^{5}$

Dalam kurun waktu 1800-1925, perubahan wilayah pemerintahan di Priangan berjalan sangat dinamis. Pada 1925, Keresidenan Priangan dipecah menjadi tiga afdeeling, yaitu Priangan Barat, Priangan Tengah, dan Priangan Timur. Ketiga wilayah afdeeling itu hanya bertahan dari 1926-1931. Pada 1931, Pemerintah Hindia Belanda menghapus Afdeeling Priangan Barat, Priangan Tengah, dan Priangan Timur. Afdeeling West-Priangan digabung dengan Afdeeling Buitenzorg dan Afdeeling Midden dan Oost Priangan disatukan dengan nama Afdeeling Pria-ngan. Pada tahun 1937, nama afdeeling diganti oleh residentie untuk menamai wilayah pemerintahan di bawah propinsi (Kleine, 1931: 134; Dienaputra, 2004: 189; Suharto, 2002: 68). Dengan adanya reorganisasi tahun 1931, wilayah Resi-dentie Priangan hanya meliputi lima kabupaten yaitu Bandung, Sumedang, Garut, Tasikma-laya, dan Ciamis $^{6}$ serta Staatsgemeente Bandung (Dienaputra, 2004: 189; de Kleine, 1931: 134; Suharto, 2002: 68).

\footnotetext{
${ }^{5}$ Pada masa kekuasaan Gubernur Jenderal $\mathrm{H}$. W. Daendels (1808-1811), Priangan menjadi Pre-fectuur Preanger Regentscappen. Pada masa kekuasaan Raffles, Priangan dijadikan sebagai salah satu keresidenan berdasarkan Resolusi tertanggal 10 Agustus 1815 . Dibentuknya pem-bagian wilyah administratif seperti ini dimak-sudkan selain untuk kepertingan politik dan keamanan juga untuk kepentingan ekonomi. Pada waktu itu, ibu kota Keresidenan Priangan di Cianjur. Pada 1864, ibu kota Keresidenan Priangan dipindahkan ke Bandung berdasarkan Besluit Tanggal 17 Agustus 1864 No. 18 (de Klein, 1931: 12, 92). Keresidenan Priangan terdiri atas lima kabupaten, yaitu Cianjur, Bandung, Sumedang, dan Parakanmuncang, dan Sukapura (van Rees, 1869: 110-113; 129).

${ }^{6}$ Sebelum dimasukkan ke wilayah Priangan, Kabupaten Ciamis merupakan bagian dari wilayah Keresidenan Cirebon. Sejak 1915, Kabupaten Ciamis menjadi bagian dari Keresidenan Priangan.
} 
Kekuasaan Belanda di Priangan berakhir tahun 1942 seiring dengan pengambilahan wilayah Indonesia oleh Jepang. Berdasarkan UU No. 29 Tahun 1942, Priangan dijadikan sebagai salah satu syuu di Pulau Jawa dengan nama Priangan Syuu sebagai pengganti Residentie Preanger (Kanpo, 1942: 10). Pada 2 September 1942 Kolonel Matsui diangkat sebagai Syuucokan di Priangan, dengan wakilnya (Fuku Syucokan) adalah R. Puradireja (Tjahaja, 2 September, 1942: 1; Kurasawa, 1993: 509). Setelah kemerdekaan Indonesia diproklamasikan tanggal 17 Agustus 1945, Panitia Persiapan Kemerdekaan Indonesia (PPKI) mengadakan sidang di bekas gedung Raad van Indie pada tanggal 18 Agustus 1945. Dalam sidang itu ditetapkan Undangundang Dasar Republik Indonesia (UUD 1945), memilih Ir. Sukarno dan Drs. Mohammad Hatta sebagai Presiden dan Wakil Presiden Republik Indonesia, membentuk Panitia Kecil yang diketuai oleh Otto Iskandar di Nata yang akan bertugas menyusun rencana mengenai halhal yang perlu segera mendapat perhatian pemerintah Republik Indonesia (Priangan Syuu, 20 Agustus 1945).

Sebagai realisasi UUD 1945 dan PP No. 2 tahun 1945 itu di Jawa Barat kemudian dibentuk 5 keresidenan, 18 kabupaten, dan 5 kotapraja. Kelima keresidenan yang dibentuk itu adalah Keresidenan Banten, Jakarta, Priangan, Bogor, dan Cirebon. Untuk menjalankan roda pemerintahan di KNID Priangan memilih dan mengangkat $R$. Puradireja sebagai Residen Priangan. Masing-masing keresidenan terdiri atas beberapa kabupaten dan kotapraja. Keresidenan Priangan terdiri atas lima kabupaten dan satu kotapraja, yaitu Kabupaten Bandung, Garut, Sumedang, Tasikmalaya, dan Ciamis, serta Kotapraja Bandung (Indonesia, 1953: 50-153). Pada masa Pemerintahan RI, pada awalnya pemerintahan keresidenan dipertahankan dengan istilah Wilayah Pembantu Guber-nur. Akan tetapi, dalam perkembangan selanjutnya, wilayah pemerintahan ini dihilangkan. Namun demikian, nama Priangan tetap hidup dalam memori kolektif masyarakat.

Meskipun perubahan wilayah pemerintahan di Priangan berjalan sa-ngat dinamis, namun sejak abad XX, pusat pemerintahan Kabupaten Garut, Kabupaten Ciamis, dan Kabupaten Ta-sikmalaya tidak mengalami perubahan, yakni di Kota Garut, Kota Ciamis, dan Kota Tasikmalaya (sejak 1901). Sebagai pusat pemerintahan, sudah tentu ketiga kota tersebut secara morfologis ber-kembang relatif lebih dinamis diban-dingkan dengan kawasan perkotaan lainnya di Priangan Timur. Pertumbuhan morfologi ketiga kota tersebut sebagai jawaban atas kebutuhan penduduk kota terhadap pemukiman, pusat rekreasi, pusat ekonomi, dan jaringan trans-portasi.

\section{Tata Ruang dan Infrastuktur Kawasan Perkotaan}

Menurut Kunto Sofianto (2001: 1112), perkembangan fisik kawasan perkotaan Garut dibagi dalam tiga periode yaitu periode pertama (1813-1920) yang menunjukkan perkembangan fisik kota secara linier. Pada periode ini, Pemerintah Hindia Belanda membangun berbagai prasarana dan sarana perkotaan untuk mengamankan kepentingannya di Kota Garut. Pemukiman penduduk diba-ngun memanjang mengikuti Societeit Straat (Jln. Societeit) ke arah Timur. Periode kedua (1920-1940) yang ditandai dengan pertumbuhan kota yang cenderung berbentuk konsentris. Bebe-rapa infrastruktur kota mulai dibangun yang lokasinya berada di pusat per-kotaan. Beberapa prasarana dan sarana perkotaan dibangun oleh pemerintah, antara lain stasiun kereta api, sekolah-sekolah, apotek, kantor pos, hotel, dan pertokoan yang mayoritas dimiliki oleh orang-orang Cina, Eropa, Jepang, dan India. Sementara itu, pusat perekono-mian masyarakat pribumi tetap di pasar. Dengan perubahan fisik kota seperti itu, kawasan perkotaan Garut 
berkembang tidak hanya sebagai pusat pemerintahan, melainkan juga sebagi pusat perekono-mian, pendidikan, dan menjadi salah satu destinasi pariwisata.
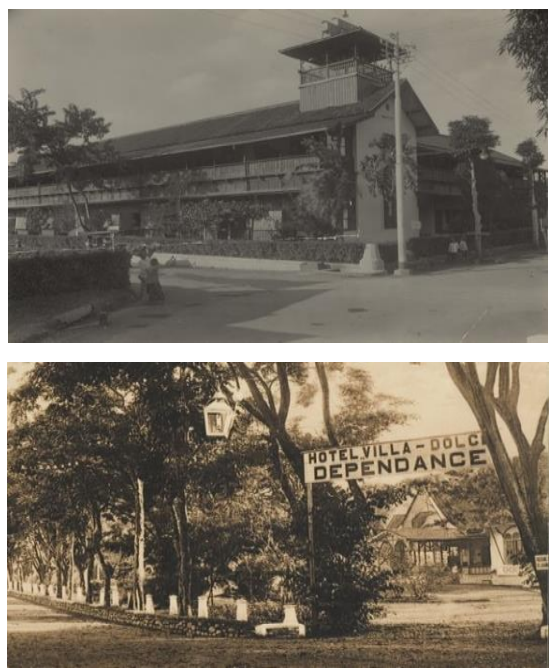

Gambar 2. Hotel Papandayan (1915) dan Hotel Villa Dolce (1930)

Sumber: KITLV Collection. Colonial Collection KIT. Code Image 151253 dan 35795. Leiden: Universiteitsbibliotheek Leiden.
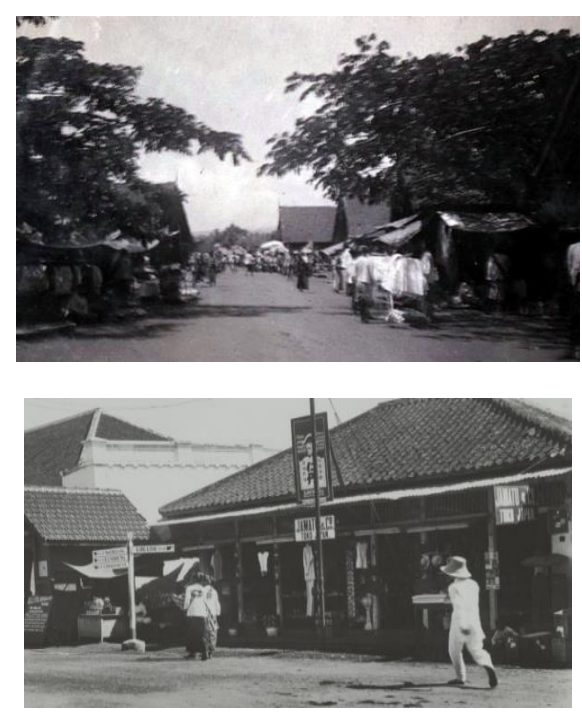

Gambar 3. Pasar Pribumi (1930) dan Toko Jepang di Garut (1940)

Sumber: KITLV Collection. Colonial Collection -

KIT. Code Image 119684 dan 5913. Leiden:

Universiteitsbibliotheek Leiden.

Periode ketiga berlangsung dalam kurun waktu 1940-1960 yang menunjukkan kecenderungan berkembang mengikuti teori inti berganda. Kondisi tersebut dapat dilihat adanya zona-zona perdagangan, pendidikan, pemukiman, dan kecenderungan pertumbuhan penduduknya. Pemukiman tidak hanya terkonsentrasi di sekitar pusat kota (wilayah sekitar alun-alun dan Jln. Jenderal A. Yani), melainkan juga dibangun di sekitar pusat kota, antara di Desa Kota Kulon dan Desa Kota Wetan. Kedua wilayah pemukiman ini meru-pakan penyangga pusat kota sehingga orientasinya tetap ke pusat kota. Pusatpusat pemukiman dibangun mengikuti arah jalan regional dan subregional sehingga Garut berkembang sebagai sebuah finger city. Kecenderungan ini dipengaruhi oleh faktor aksesibilitas sehingga bisa memperlancar pergerakan orang maupun barang. Pertumbuhan kota Garut sebagaimana diuraikan ter-sebut, dapat dilihat pada peta berikut.

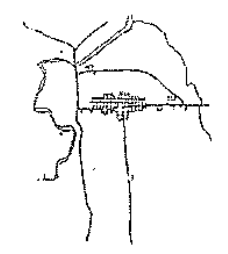

\pm Tahun 1850

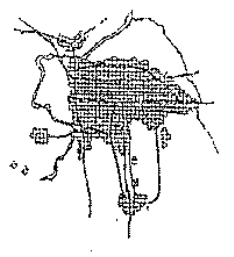

\pm Tahun 1920

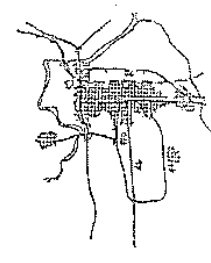

\pm Tahun 1940

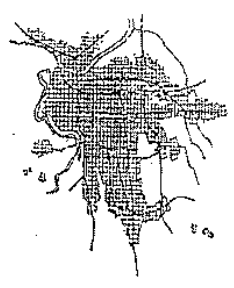

\pm Tahun 1967
Gambar 4. Perubahan Fisik Kota Garut Tahun 1850 - 1967

Sumber: Sofianto, 2001: 174.

Dari peta tersebut jelas terlihat bahwa pertumbuhan pemukiman di Kota Garut menunjukkan kecenderungan ke arah Selatan-Timur. Hal tersebut dapat dipahami karena tanahnya datar, sedangkan ke arah Utara-Barat sulit untuk 
dijadikan sebagai pemukiman meng-ingat terdapat gunung.

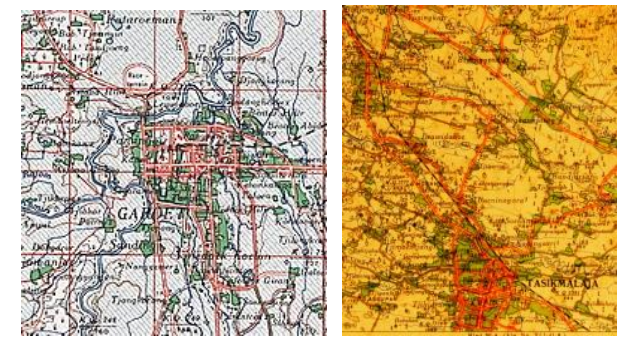

Gambar 5. Peta Topografi Pusat Kota Garut dan Tasikmalaya pada Abad Ke-20

Sumber: Ronald Gilbert Gill. 1995. De Indische Stad op Java en Madoera; Een Morfologische Studie van haar Ontwikkeling. Delft: Technische Universiteit Delft. Hlm. 210; Koleksi Arsip Kartografi Indonesia 1913-1946. No. 744/Blad 49 n/24. Jakarta: ANRI.

Sementara itu, pada awal Abad XX, secara morfologis tata ruang kota Ciamis memperlihatkan pola kota lurus dengan pusatnya alun-alun yang meminjam istilah R. G. Gill (1995: 200) dinamai horizontale ladder-structuur (struktur tangga horisontal). Pola kota seperti menunjukkan bahwa sentral kota berada di alun-alun dan bangunan pemerintahan serta pemukim-an secara berjenjang ditempatkan mem-bujur ke arah Barat dan Timur sehingga membentuk kawasan perkotaan yang horisontal.

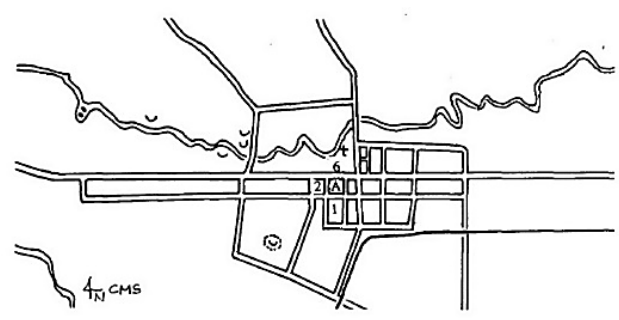

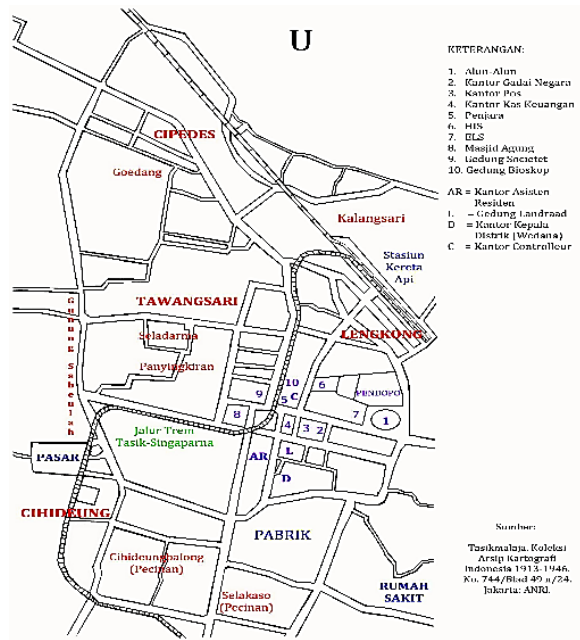

Gambar 6. Pola Tata Ruang Pusat Kota Ciamis dan Tasikmalaya pada Abad Ke-20

Sumber: Ronald Gilbert Gill. 1995. De Indische Stad op Java en Madoera; Een Morfologische Studie van haar Ontwikkeling. Delft: Technische Universiteit

Delft. Hlm. 200; Diolah dari Koleksi Arsip

Kartografi Indonesia 1913-1946. No. 744/Blad 49 n/24. Jakarta: ANRI.

Pada Abad XIX, prasarana transportasi di Kota Garut umumnya masih berupa jalan tanah yang dipadatkan. Kondisinya semakin membaik seiring ditemukannya aspal untuk mengeraskan jalan. Jaringan jalan di Kota Garut pada umumnya sudah bagus sehingga memperlancar pergerakan manusia dan ba-rang. Memasuki Abad XX, infrastruktur kota di Garut semakin berkembang karena kedudukannya sebagai salah satu destinasi wisata.

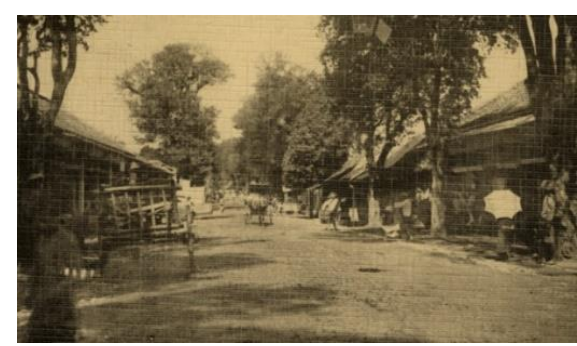




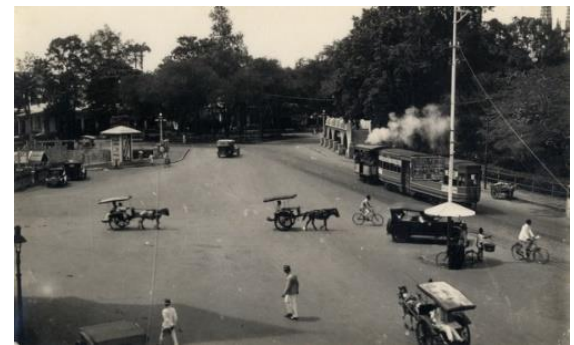

Gambar 7. Pengkolan dan Trem di Kota Garut Tahun 1930

Sumber: KITLV Collection. Colonial Collection KIT. Code Image 1402233 dan 181842. Leiden: Universiteitsbibliotheek Leiden.
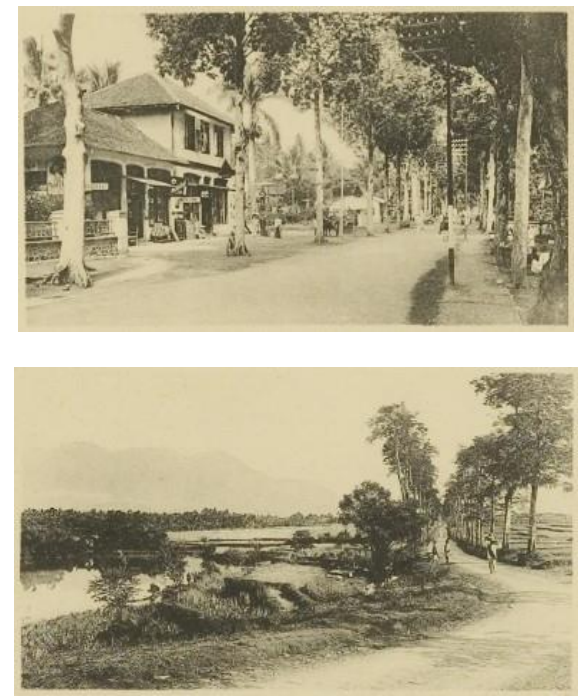

Gambar 8. Jalan Utama dan Jalan Talun di Garut, Tahun 1930

Sumber: KITLV Collection. Colonial Collection KIT. Code Image 11913 dan 11914. Leiden: Universiteitsbibliotheek Leiden.

Selain itu, banyaknya areal perkebunan di Garut Selatan menjadikan Kota Garut sebagai tempat penyimpanan hasil perkebunan. Hal tersebut memerlukan prasarana dan sarana transportasi yang memadai. Untuk mendukung pergerakan manusia dan barang, pemerintah membangun jaringan transportasi trem sehingga mejadikan Garut lebih "ramai" lagi.

Baik di Kota Garut maupun Cia-mis, tata ruang kotanya masih menj-adikan alun-alun sebagai pusat aktivitas warganya. Namun demikian, saat ini alunalun memiliki fungsi yang berbeda dengan alun-alun masa lampau. Apa sebenarnya alun-alun itu? Dalam Encyclopedie van Nederlandsch Indie (Paulus, 1917: 31) dituliskan bahwa di hampir setiap tempat kediaman bupati atau kepala distrik di Pulau Jawa, selalu dijumpai sebuah lapangan rumput yang luas, yang dikelilingi oleh pohon beri-ngin di tengahnya. Lapangan inilah yang dinamakan 'alun-alun'. Di Jawa Barat juga terdapat alun-alun kecil di depan rumah kepala desa, tetapi tidak setiap alun-alun terdapat pohon beringin. Mesjid seringkali terdapat di sebelah Barat dari alun-alun.
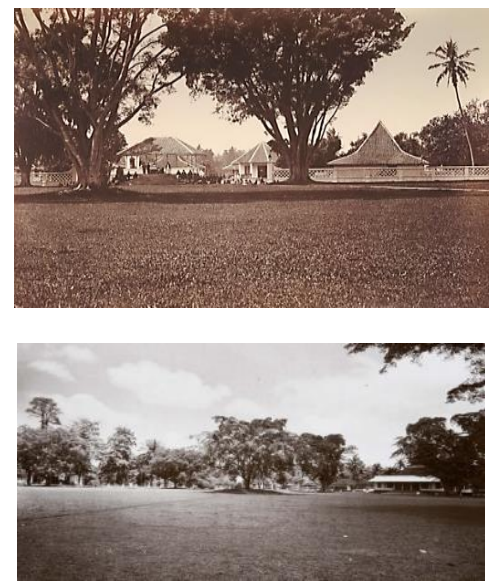

Gambar 9. Alun-Alun Garut (1890) dan AlunAlun Ciamis (1933)

Sumber: KITLV Collection. Colonial Collection KIT. Code Image 106902. Leiden:

Universiteitsbibliotheek Leiden; Aloen-Aloen in Tjiamis. 1933. Koleksi Tropenmuseum. Amsterdam.

Pada masa pra-kolonial, alun-alun merupakan bagian tak terpisahkan dari kompleks keraton atau tempat tinggal penguasa daerah. Alun-alun merupakan daerah sakral tempat pertemuan antara raja dengan para bawahannya atau kalau di daerah antara bupati dengan para bawahannya. Berbagai acara ritual, dilaksanakan di alun-alun sehingga alun-alun tidak bisa disamakan dengan sebut-an sekarang "taman kota". Alun-alun merupakan pusat tata kota tradisional yang dikelilingi oleh bangunan-bangun-an sakral yakni keraton atau pendopo yang melambangkan pusat kekuasaan mikrokosmos dan mesjid sebagai lam-bang pusat 
kekuasaan makrokosmos. Posisi keraton atau pendopo biasanya meng-hadap ke Utara atau menghadap ke sebuah gunung yang dianggap keramat (Handinoto, 1992).
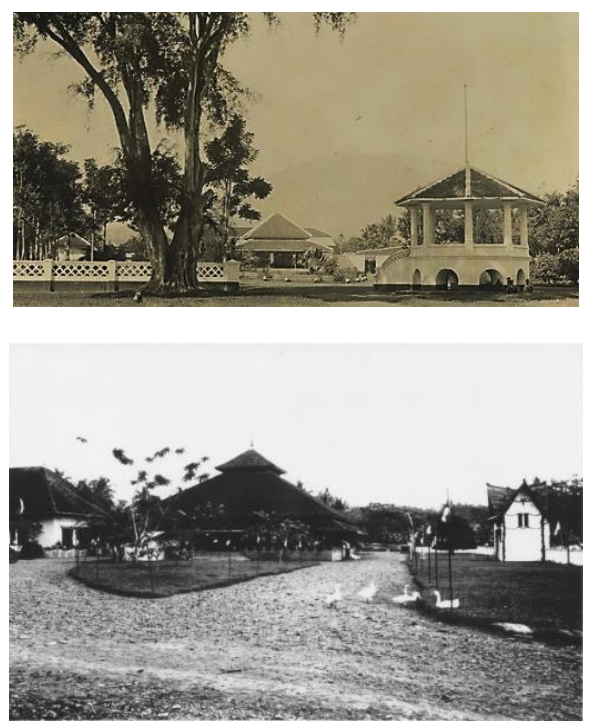

Gambar 10. Pendopo Garut (1900) dan Pendopo Tasikmalaya (1923)

Sumber: KITLV Collection. Colonial Collection KIT. Code Image 116454. Leiden:

Universiteitsbibliotheek Leiden; Data Informasi Arsip Foto. Koleksi KIT Wilayah Jabar. No.

Inventaris. 0186/028. Jakarta: Arsip Nasional RI.

Pada masa kolonial, Pemerintah Hindia Belanda membiarkan keberadaan alun-alun karena dipandang dapat dimanfaatkan untuk kepentingan politik-nya. Namun demikian, fungsi alun-alun sedikit demi sedikit mengalami per-geseran karena mulai dipakai sebagai kegiatan yang bersifat profan. Alun-alun sering dipergunakan sebagai pusat akti-vitas masyarakat kota, antara lain olah raga, pertunjukan seni, dan sebagainya. Untuk kepentingan politiknya, Peme-rintah Hindia Belanda membangun rumah dan/atau asisten residen di sekitar alunalun juga. Hal itu dilakukan karena pemerintah kolonial memahami betul bahwa alun-alun dengan bangunan sakral di sekitarnya merupakan pusat kekuasaan tradisional (Handinoto, 1992). Ketika NKRI berdiri, alun-alun benar-benar diubah fungsinya karena bukanlah lagi sebagai tempat sakral (tempat pertemuan bupati dengan bawa-han atau rakyatnya), melainkan difung-sikan sebagai taman kota, seperti yang terjadi di Garut, Tasikmalaya, dan Cia-mis. Alun-alun di ketiga kota tersebut benar-benar telah berubah fungsi men-jadi ruang publik, bukan lagi sebagai ruang sakral tempat "bercengkerama-nya" bupati dengan rakyatnya (Handi-noto, 1992).

\section{Simbol-Simbol Kawasan Perkotaan}

Simbol kota merupakan simbolsimbol yang terbuka untuk umum sehingga masyarakat dapat mengakses-nya dan mencakup keseluruhan simbol, termasuk di dalamnya rumah-rumah penduduk (Nas, 1993: 61). Berkaitan dengan konsep itu, ada simbol kota yang memiliki keterkaitan dengan kelompok masyarakat tertentu, ada juga simbol kota yang bersifat netral atau tidak terkait dengan kelompok masyarakat tertentu. Simbol kota menjadi salah satu media untuk mengenali identitas budaya sebuah kota. Artinya, ketika suatu daerah memiliki ciri khas tertentu yang kemudian disimbolisasikan dalam ben-tuk monumen, gerbang kota, lambang kota, atau bangunan khas, maka masya-rakat akan tahu keterkaitan simbol-simbol itu dengan daerah tempat simbol kota itu dibangun.
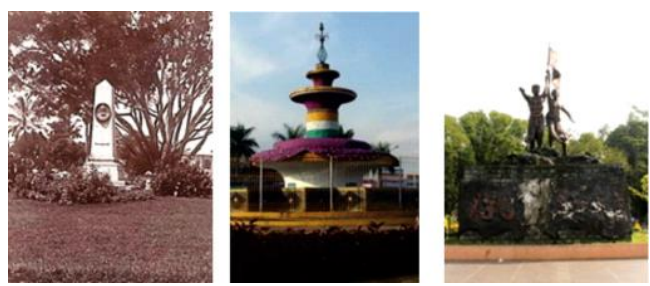

Gambar 11. Monumen K. F. Holle di AlunAlun Garut (1910), Monumen Rafflesia di Alun-Alun Ciamis; serta Monumen Mak Eroh dan Abdul Rojak di Alun-Alun Tasik Sumber: Monument van Karel Frederik Holle, Theeplanter, te Garoet. 1910. Colonial Collection KIT. Code Image 103922. Leiden: Bibliotheek Universiteit Leiden - KITLV Collection; Dokumentasi Peneliti, 2015.

Di Garut, yang dikenal dengan perkebunan-perkebunan tehnya di dae-rah Garut Selatan, menjadikan daerah tersebut 
banyak dikunjungi oleh wisa-tawan. Di sisi lain, keberadaan perke-bunan-perkebunan itu menjadikan Garut sebagai salah satu kabupaten penting dalam kaca mata politik ekonomi pemerintah kolonial. Masyarakat tahu bahwa ketika berbicara perkebunan di Garut, maka selalu dikaitkan dengan seorang Belanda yang bernama Karel Frederick Holle. Dialah yang merintis pembukaan perkebunan di Garut Sela-tan. Untuk mengenang jasanya, dibuat-kanlah sebuah monumen di alun-alun Garut berbentuk lingga yang diberi gambar wajah K. F. Holle.

Alun-alun Kota Ciamis dan Kota Tasikmalaya pun memiliki monumen yang menggambarkan karaktersitik kota tersebut. Alun-alun Kota Ciamis diperindah dengan monumen Bunga Rafflesia sehingga alun-alun tersebut dikenal juga dengan Taman Rafflesia. Sementara itu, alun-alun Kota Tasikmalaya dilengkapi dengan sebuah monumen yang berkaitan dengan peraih kalapataru, yakni Mak Eroh dan Abdul Rojak.

Selain monumen yang terletak di alun-alun, kawasan perkotaan Garut dan Tasikmalaya diperindah pula dengan monumen-monumen yang memiliki hubungan dengan kondisi, karakter, atau peristiwa tertentu. Di Garut, misalnya, cukup banyak dibangun monumen yang pada umumnya berkaitan dengan nilai-nilai historis kawasan perkotaan Garut, salah satunya monumen "Garut Kota Intan" di Simpang Kerkhof, Kota Garut. Monumen itu berbentuk tugu yang di puncaknya dibuatkan bentuk intan berwarna merah.
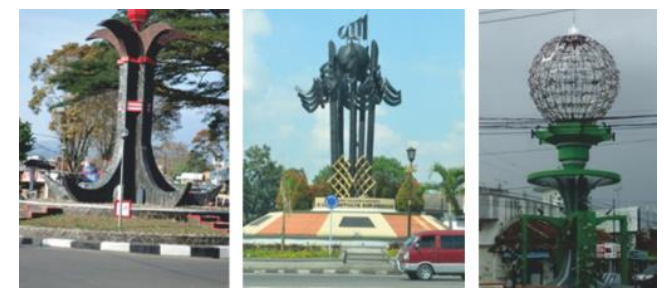

Gambar 12. Monumen Garut Kota Intan dan Monumen Pahlawan Nasional K. H. Z. Mustofa serta Monumen Asmaul Husna di Kota Tasikmalaya

Sumber: Dokumentasi Peneliti, 2015 dan 2016.
Di Kota Tasikmalaya, yang dike-nal dengan julukan kota santri, dibangun beberapa monumen yang memper-lihatkan nilai religi yang begitu kuat, antara lain Monumen Asmaul Husna di ujung sebelah Selatan Jln. K. H. Mustofa (persimpangan Nagarawangi). Sementara di Bundaran Jln. Mang-kubumi - Ir. Juanda, dibangun sebuah tugu peringatan perjuangan $\mathrm{K}$. $\mathrm{H}$. Zainal Mustofa yang berjuang melawan Jepang pada 1943. Menarik disimak bahwa di atas tugu atau monumen, baik yang lama maupun yang baru selalu ada lafadz Allah. Hal ini merupakan penegasan terhadap julukan sebagai Kota Tasik-malaya sebagai kota santri.

Selain monumen yang menunjukkan perbedaan, terdapat juga monumen yang menunjukkan makna sama, yaitu monumen adipura sebagai simbol keberhasilan meraih penghargaan dalam kebersihan kota. Pembangunan tugu ter-sebut seakan menjadi keseragaman kare-na di puncak tugu pasti terdapat replika piala adipura. Baik di Garut, Ciamis, maupun Tasikmalaya, dalam monumen tersebut tidak terdapat diorama yang menggambarkan perjuangan meraih adipura. Pembangunan monumen terse-but lebih ditujukan untuk mengingatkan masyarakat tentang pentingnya menjaga kebersihan dan keindahan kota.
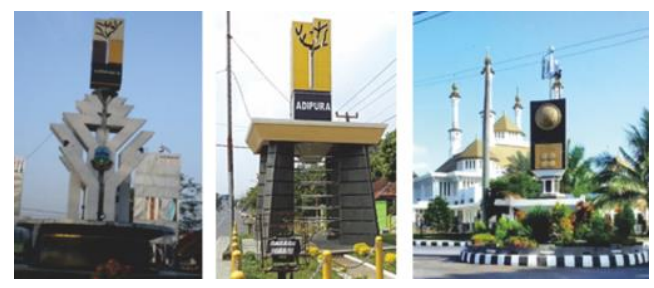

\section{Gambar 13. Monumen Adipura di Kota Garut, Ciamis, dan Tasikmalaya Sumber: Dokumentasi Tim Peneliti, 2015.}

\section{PENUTUP}

Dari pemaparan yang telah dilakukan dapat disimpulkan bahwa secara morfologis, pertumbuhan kota Garut, Ciamis, dan Tasikmalaya menun-jukkan kecenderungan yang berbeda meskipun 
sama-sama berangkat dari kota tradisional. Dari aspek tata ruang kota, Kota Tasikmalaya sangat berbeda dengan Kota Garut dan Camis. Hal ter-sebut dapat dilihat dari unsur pembentuk kota yang tidak sesuai dengan konsep tata ruang kota tradisional. Selain itu, beberapa simbol kota menunjukkan ke-seragaman meskipun secara artistik memiliki perbedaan makna. Monumen-monumen yang dibangun di ketiga kota tersebut menunjukkan adanya keterkait-an dengan karakter masyarakat, julukan pihak luar terhadap kota tersebut, dan persitiwa yang pernah terjadi di kotakota tersebut.

\section{DAFTAR SUMBER}

\section{Arsip, Fotografi, Kartografi, dan Sumber Resmi Tercetak}

Aloen-Aloen in Tjiamis. 1933.

Koleksi Tropenmuseum. Amsterdam.

De Pengkollan te Garoet. 1905.

KITLV Collection. Colonial Collection KIT. Code Image 1402233. Leiden: Universiteisbibliotheek Leiden.

De regentswoning te Garoet. 1900. KITLV Collection. Colonial Collection KIT. Code Image 116454. Leiden: Universiteisbibliotheek Leiden.

Hoofdweg te Garoet. 1930. KITLV Collection. Colonial Collection KIT. Code Image 11913. Leiden: Universiteisbibliotheek Leiden.

Hotel Papandajan te Garoet. 1915. KITLV Collection. Colonial Collection KIT. Code Image 151253. Leiden: Universiteisbibliotheek Leiden.

Japaanse Toko te Garoet. 1940. KITLV Collection. Colonial Collection KIT. Code Image 5913. Leiden: Universiteisbibliotheek Leiden.

Monument van Karel Frederik Holle, Theeplanter, te Garoet. 1910.

KITLV Collection. Colonial Collection KIT. Code Image 103922. Leiden: Universiteisbibliotheek Leiden.

Pasar te Garoet. 1930.

KITLV Collection. Colonial Collection KIT. Code Image 119684. Leiden: Universiteisbibliotheek Leiden.
Plein, vermoedelijk de aloen-aloen te Garoet. 1890.

KITLV Collection. Colonial Collection KIT. Code Image 106902. Leiden: Universiteisbibliotheek Leiden.

Staatsblad van Nederlandsch-Indie. No. 674/1918; No. 216/1922; No. 79/1924; No. 386/1925; No. 387/1925; No. 388/1925; No. 389/1925; No. 390/1925; No. 391/1925; No. 392/1925; No. 369/1926.

Straatweg langs Hotel Villa Dolce met de dependance van het hotel, Garoet. 1930. KITLV Collection. Colonial Collection KIT. Code Image 35795. Leiden: Universiteisbibliotheek Leiden.

Taloenweg te Garoet. 1930. KITLV Collection. Colonial Collection KIT. Code Image 11914. Leiden: Universiteisbibliotheek Leiden.

Tasikmalaja. Koleksi Arsip Kartografi Indonesia 19131946. No. 744/Blad 49 n/24. Jakarta: ANRI.

Tram te Garoet 1930. KITLV Collection. Colonial Collection KIT. Code Image 181842. Leiden: Universiteisbibliotheek Leiden.

Woning van de assistent-resident te Garoet. 1904.

KITLV Collection. Colonial Collection KIT. Code Image 10625. Leiden: Universiteisbibliotheek Leiden.

\section{Artkel, Buku, Disertasi, dan Tesis}

Antariksa. 2008.

Memahami Sejarah Kota; Sebuah Pengantar. Jakarta: t.p.

Bijlagen Behoorende bij de Nota over eene Reorganisatie van het Binnenlandsch Bestuur op Java en Madoera. 1907. Batavia: Landsdrukkerij.

Buys, M. 1891. Batavia, Buitenzorg, en de Preanger; Gids voor Bezoekers en Toeristen. Batavia: G. Kolff \& Co.

van der Chjis, J. A. 1880.

Babad Tanah Pasundan. Terj. Raden Karta Winata. Batavia: Kantor Citak Gupernemen.

Dienaputra, Reiza D. 2004. 
Cianjur: Antara Priangan dan Buitenzorg, Sejarah Cikal Bakal Cianjur dan Perkembangannya hingga 1942. Bandung: Prolitera.

Djajadiningrat, R. A. Hoesein. 1913/1983. Critische Beschouwing van de Sadjarah Banten: Bijdrage ter Kenstscheteing van de Javaansche Geschiedschrijving. Leiden: John Enschede en Zenen.

Ekadjati, Edi S. (ed.). 1984.

Masyarakat Sunda dan Kebudayaannya. Jakarta: Girimukti Pasaka.

Ekadjati, Edi S. 1982.

Sejarah Revolusi Kemerdekaan Daerah Jawa Barat. Jakarta: Departemen Pendidikan dan Kebudayaan.

Falah, Miftahul. 2009.

"Pertumbuhan Kota Tasikmalaya, 18201942; Dari Kota Distrik menjadi Kota Kabupaten". Metahumaniora. Vol 1, No. 2, Agustus 2009. Hlm. 200-216. 2010.

Sejarah Kota Tasikmalaya, 1820-1942. Bandung: Uga Tata Sunda.

Falah, Miftahul. 2012.

"Pers di Kota Tasikmalaya, 1900-1942". Sosiohumaniora. Vol 14, No. 2, Juli 2012. Hlm. 116-131.

Gill, Ronald Gilbert. 1995.

De Indische Stad op Java en Madoera; Een Morfologische Studie van haar Ontwikkeling. Delft: Technische Universiteit Delft.

Gottschalk, Louis. 1968. Understanding History; A Primer of Historical Method. $2^{\text {nd }}$ Edition. New York: Albert de Knopf.

Hageman, J. 1869. "Geschiedenis der Soendalanden”. TBG. XVI.

Indonesia. Kementrian Penerangan. 1953. Propinsi Djawa Barat. Djakarta: Dewaruci Press.

Kartodirdjo, Sartono. 1993. Pengantar Sejarah Indonesia Baru; Sejarah Pergerakan Nasional: dari Kolonialisme sampai Imperialisme. Jilid 2. Cet. Ke-3. Jakarta: Gramedia.

de Klein, Jacob Wouter. 1931.
Het Preangerstelsel (1677-1871) en zijn Nawerking. Delf: de NV Technische Boekhandel en J. Waltman Jr.

Kurasawa, Aiko. 1993.

Mobilisasi dan Kontrol: Studi tentang Perubahan Sosial di Pedesaan Jawa 1942-1945. Jakarta: Grasindo.

Lubis, Nina H. 1998

Kehidupan Kaum Menak Priangan (18001042). Bandung: Pusat Informasi Kebudayaan Sunda.

Muhsin Z., Mumuh. 2010. "Priangan Abad Ke-19; Tinjauan Seja-rah dan Demografi". Metahumaniora. Vol 1, Nomor 4, April 2010. Hlm. 367-378. 2011.

"Dinamika Sosial Ekonomi Priangan Abad Ke-19. Sosiohumaniora. Vol 13, Nomor 1, Maret 2011. Hlm. 96-107. 2011.

Terbentuknya Keresidenan Priangan. Bandung.

Nash, Peter J.M (ed). 2011. Cities Full of Symbols; A Theory of Urban Space and Culture. Leiden: Leiden Universiteit Press.

Paulus. 1917.

Encyclopaedie van Nederlandsch Indie (ENI). III deel.'s Gravenhage: Martinus Nijhoff.

van Rees, Otto. 1880. Overzigt van de Geschiedenis der Preanger Regentschappen. Batavia.

Sjoberg, Gideon. 1965.

The Preindustrial City: Past and Present. London: Collier-Macmillan

Sofianto, Kunto. 2008. Garut Kota Intan; Sejarah Kota Garut. Bandung: Satya Historika.

Stibbe, D. G. 1919.

"Tasikmalaja" dalam Encyclopaedie van Nederlandsch-Indie. Tweede Druk. Veerde Deel (Soemb - Z). Hlm. 284-285. s'Gravenhage: Martinus Nijhoff.

Suharto. 2002.

Pagoejoeban Pasoendan 1927-1942; Profil Pergerakan Etno-Nasionalis. Bandung: Lembaga Kajian Strategis Paguyuban Pasundan. 
Yulifar, Lely. 2014

Kabupaten Galuh-Ciamis, 1809-1942.

(Pemerintahan, Sosial-Ekonomi, dan

Politik). Disertasi. Bandung: Program PPs FIB Unpad.

Yunus, Hadi Sabari 1982.

Manajemen Kota. Yogyakarta : Pustaka

Pelajar.

\section{Media Massa}

Kanpo, 1942.

Priangan Syuu, 20 Agustus 1945.

Tjahaja, 2 September, 1942. 